\title{
Space-Temporal analysis of suspended sediment in low concentration reservoir by remote sensing
}

\section{Análise espaço-temporal dos sedimentos em suspensão em reservatório de baixa concentração por meio de sensoriamento remoto}

\author{
Giancarlo Brugnara Chelotti ${ }^{1}$ (D), Jean Michel Martinez ${ }^{2}$, Henrique Llacer Roig ${ }^{1}$ and Diogo Olivietti ${ }^{1}$ \\ ${ }^{1}$ Programa de Pós-graduação em Geociências Aplicadas e Geodinâmica, Universidade de Brasilia, Brasília, DF, Brasil \\ ${ }^{2}$ Institute de Recherche e Development, Toulose, França \\ E-mails: giancarlo.chelotti@gmail.com (GBC), martinez@ird.fr JMM),roig@unb.br (HLR), di_olivietti@hotmail.com (DO)
}

Received: April 18, 2018 - Revised: January 20, 2019 - Accepted: February 17, 2019

\begin{abstract}
The study of small reservoirs with low suspended sediment concentration (CSS) is still a challenge for remote sensing. In this work we estimate CSS from the optical properties of water and orbital imagery. Campaigns were carried out at selected dates according to the calendar of sensor passages, rainfall seasonality and hydrograph of the reservoir for the collection of surface water samples and field spectroradiometry. The calibration between CSS and spectral behavior generated CSS estimation models from MODIS and Landsat 8 data, allowing investigation of their temporal and spatial behavior. The MODIS model generated a time series of CSS from 2000 to 2017, presenting $\mathrm{R}^{2}=0.8105$ and $\mathrm{RMSE} \%=39.91 \%$. The Landsat 8 model allowed the spatial analysis of CSS, with $\mathrm{R}^{2}=0.8352$ and RMSE $\%=15.12 \%$. The combination of the proposed models allowed the temporal and spatial analysis of the CSS and its relationships with the rainfall regime and the quota variation of the Descoberto reservoir (DF). The results showed that the use of orbital data complements the CSS information obtained by the traditional methods of collecting and analyzing water quality in low CSS reservoirs.
\end{abstract}

Keywords: Water quality; Hydrological and environmental modeling; Remote Sensing; MODIS; Landsat 8.

\section{RESUMO}

O estudo de pequenos reservatórios e com baixa concentração de sedimentos em suspensão (CSS) ainda é um desafio para o sensoriamento remoto. Neste trabalho estimamos a CSS a partir das propriedades óticas da água e de imagens orbitais. Realizamos campanhas em datas escolhidas em função do calendário de passagem dos sensores, sazonalidade das chuvas e hidrograma do reservatório para coleta de amostras de água superficial e espectrorradiometria de campo. A calibração entre a CSS e o comportamento espectral gerou modelos de estimativa de CSS a partir de dados MODIS e Landsat 8, permitindo investigação do seu comportamento temporal e espacial. O modelo MODIS gerou uma série temporal de CSS desde 2000 a 2017, apresentando $\mathrm{R}^{2}=0,8105$ e RMSE $\%=39,91 \%$. O modelo Landsat 8 permitiu a análise espacial da CSS, apresentando $\mathrm{R}^{2}=0,8352$ e RMSE $\%=15,12 \%$. A combinação dos modelos propostos permitiu a análise temporal e espacial da CSS e seus relacionamentos com o regime de chuvas e variação de cota do reservatório do Descoberto (DF). Os resultados demonstraram que o uso de dados orbitais complementam as informações da CSS obtidas pelos métodos tradicionais de coleta e análise de qualidade da água em reservatórios de baixa CSS.

Palavras-chave: Qualidade das águas; Modelagem hidrológica e ambiental; Sensoriamento remoto; MODIS; Landsat 8. 


\section{INTRODUCTION}

Sediment deposition in reservoirs causes silting, altering water quality and reducing its capacity and useful life. A high sediment concentration reduces the transmission of solar radiation, interfering the photosynthesis of aquatic vegetation and phytoplankton, altering the aquatic ecosystem (JENSEN, 2009). This scenario reflects an increase in costs for the maintenance of reservoirs and for the water treatment for consumption.

Correct monitoring of water quality parameters in water bodies is often difficult, because this monitoring is primarily based on sample collection at hydrological stations. In such cases, monitoring efficiency is directly related to sampling location and frequency. (MARTINEZ et al., 2015). It is common for reservoir monitoring to be insufficient in Brazil due to the low collection frequency and low sample density (BESKOW et al., 2016).

The Descoberto reservoir is responsible for supplying $60 \%$ of the Distrito Federal (ADASA, 2016). In recent years, the Water Treatment Station of Descoberto has registered a growth in the percentage of sludge and water turbidity, as result of the environmental degradation of the region of influence of the lake (DISTRITO FEDERAL, 2009). The increased sediment deposition, associated to the water shortage crisis, verified at the present moment, reinforces the need for monitoring, protection and recovery of the Descoberto Basin.

The Alto Descoberto Basin (BHAD) has twelve hydrological monitoring stations, eleven of which are in tributaries of the reservoir and the only monitoring point of the water quality monitoring in the reservoir is located in the dam (DISTRITO FEDERAL, 2009). Although there are several sediment entry sites in the reservoir, these are not properly monitored.

Remote sensing is an efficient tool for hydrological monitoring in large rivers and lakes, as it allows to relate, by satellite, the color of the water to its content (PINTO et al., 2014; VILLAR et al., 2012; GERACE et al., 2013; MARTINEZ et al., 2015). The advantage of hydrological monitoring by satellite images in relation to hydrological stations is that the entire surface of the water body can be monitored with high frequency, depending on the temporal resolution of the satellite used (OYAMA et al., 2009).

Chen et al. (2015) cataloged several studies to estimate total suspended solids (TSS) through the MODIS sensor in inland waters on all continents. These studies were carried out mainly in large rivers and lakes, and especially where TSS is higher or with high variability (TSS between 5 and $500 \mathrm{mg} / \mathrm{L}$ ) (VILLAR et al., 2012; MARTINEZ et al., 2015; SANTOS et al., 2018; VILLAR et al., 2018). The initiatives to use MODtIS data in small reservoirs and low sediment concentration sites are rare.

For more than thirty years, the Landsat family sensors have been used to analyze water quality parameters (LILLESAND et al., 1983). Suspended sediments were mainly studied by Landsat 5 and 7 (MONTANHER; SOUZA FILHO, 2015; DUARTE et al., 2016; SHAHZAD et al., 2018). With the launch of Landsat 8 Satellite, in 2013, the possibilities of studies in reservoirs have expanded. The OLI sensor has two more bands than its antecessors and produces 12-bit images, raising the potential of hydrologic studies with remote sensing (GERACE et al., 2013).

The Landsat 8 data are already being used to estimate turbidity and sediment concentration (VANHELLEMONT; RUDDICK, 2014; CHALOV et al., 2017; KO et al., 2017; YEPEZ, et al., 2018; MANZO et al., 2018; MARKET et al., 2018). Most of these studies were carried out in large rivers or estuarine regions with higher TSS variability (TSS between 5 and $100 \mathrm{mg} / \mathrm{l}$ ). There was a gap in the study of small reservoirs with more homogeneous characteristics and low TSS, such as water supply reservoirs for large urban centers.

While MODIS images have better temporal resolution and worse spatial resolution, OLI images have better spatial resolution and worse temporal resolution. These sensors, therefore, produce potentially complementary data for the hydrological study, allowing a spatial and systematic monitoring.

With the purpose of filling the hydrological monitoring gap of small reservoirs for human supply, the aim of this work was to estimate reservoir suspension sediment concentrations (CSS) from the optical properties of water and the use of satellite imagery. This allows the temporal, seasonal and spatial analysis of suspended sediments, and their relationships with the climate.

\section{METHODS}

The methodology applied in the present work followed the flowchart proposed in figure 1.

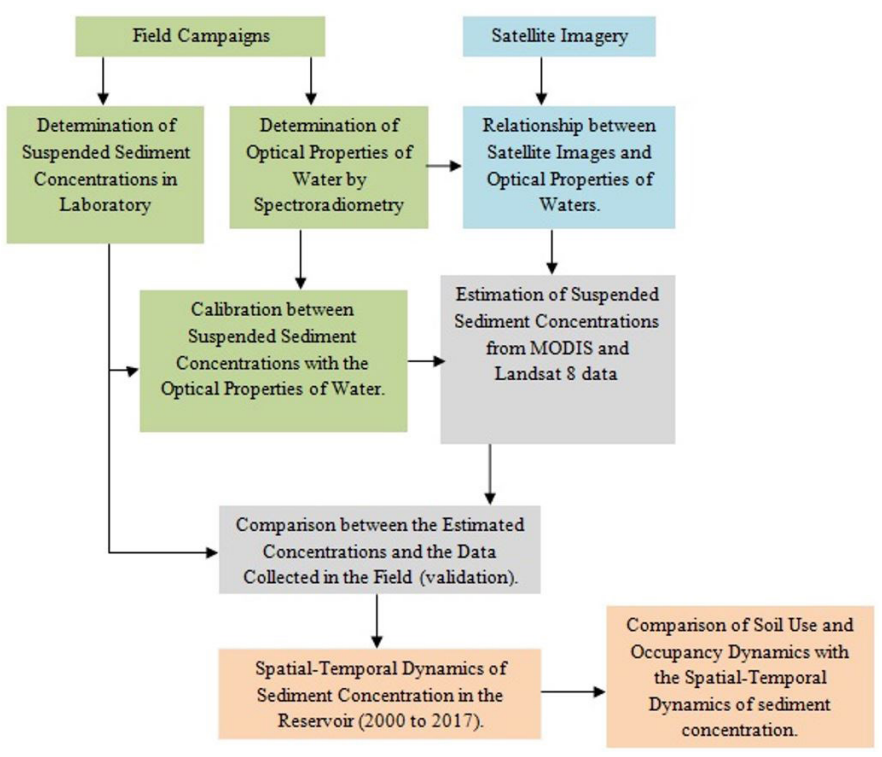

Figure 1. Flowchart of the study methodology. 


\section{Study area}

The Descoberto reservoir was created in 1974 and has 1,255 ha of extent, being the most important water catchment of the Distrito Federal - DF. BHAD is located in the West Central region, part in DF and another in the State of Goiás (GO), having inside the city of Brazlândia (DF) and part of the cities of Taguatinga and Ceilândia (DF) and Águas Lindas (GO), covering an area of $452 \mathrm{~km}^{2}$, according to the situation map shown in figure 2 .

This basin has a tropical climate Aw according to the Koppen classification (KÖPPEN, 1948) with two well defined seasons: a rainy period from October to March and a dry season from April to September. About the morphology, BHAD has a shape factor (HORTON, 1932) of 0.644 and Circularity Index (MÜLLER, 1953) of 0.603.

\section{Field surveys}

Three field campaigns were carried out, two of which were on $03 / 15 / 2016$ and 10/09/2016, dates of the Landsat 8 satellite imaging. The dates were also chosen according to the seasonality of the rains and the hydrograph of the reservoir, that on $03 / 15 / 2016$ the reservoir was in the maximum quota, as a result of being the end of the rainy season; on $9 / 10 / 2016$ it was with $21 \%$ of its capacity, having already restarted the rainy season.

Water samples were collected at the surface level at the main water entrance points of the reservoir (Descoberto river, Rocinha, Coqueiro, Queimado, Rodeador and Das Pedras streams); also in the center and near the dam of the reservoir, totaling eight points per field campaign, as shown in figure 3.

These samples were submitted to laboratory analysis for CSS determination, by filtration using $0.45 \mu \mathrm{m}$ paper filters, filtering the samples until filter saturation. The protocol of analysis followed the methodology Standard Methods (APHA, 1998).

At the collection points, the optical properties of the surface waters were also determined by the in situ reflectance measurements, using the Ramses spectroradiometer, from the manufacturer Trios. This equipment consists of a set of three

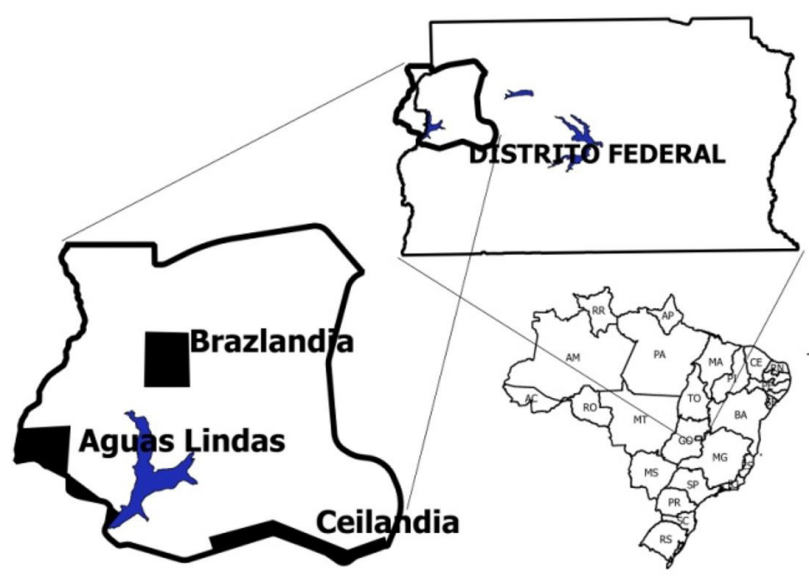

Figure 2. Situation map of Alto Descoberto Basin. hyperspectral sensors, capable of detecting between the visible and near infrared (NIR) bands of the electromagnetic spectrum, with a spectral detection range of 320 to $950 \mathrm{~nm}$ along 256 bands (TRIOS, 2010).

This method allows obtaining data from a target at a distance of one meter, with atmospheric effects only of the radiation incident on the target. The atmospheric effects of reflected radiation are practically zero. These devices return the spectral behavior of the targets, forming a practically continuous spectrum. This can be correlated with the bands of a multispectral sensor (RUDORFF et al., 2007).

The equipment was installed in a vessel with the irradiance sensor $\left(E_{d}\right)$ pointed at the sky in NADIR, the sky radiance sensor $\left(L_{d}\right)$ with a zenith angle of approximately $40^{\circ}$ and the water radiance sensor $\left(\mathrm{L}_{\mathrm{u}}\right)$, with $40^{\circ}$ off nadir, as shown in Figure 4 . The values of the angles for acquisition geometry were defined based on Villar et al. (2012).

In this configuration, one sensor measures $\mathrm{E}_{\mathrm{d}}$, another $\mathrm{L}_{\mathrm{d}}$ and another $\mathrm{L}_{\mathrm{u}}$, which is the parameter of interest. However, the $\mathrm{L}_{\mathrm{u}}$ sensor also registers a fraction of energy from the sky, and therefore $L_{d}$, which reflects on the surface of the water towards the sensor. The simultaneous use of these three sensors allows to know the fraction of $\mathrm{L}_{\mathrm{d}}$ that interferes in the water radiance and, later, to remove it.

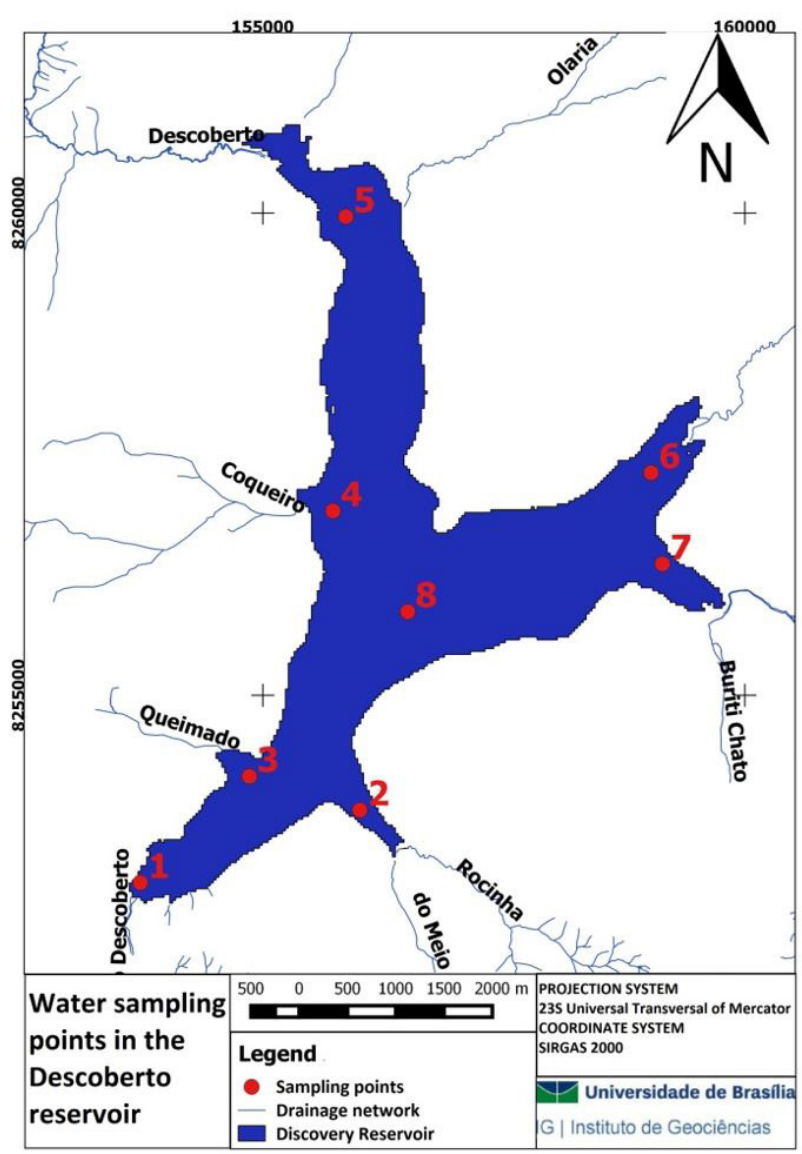

Figure 3. Scheme of water sampling points in the Descoberto reservoir. 
The main radiometric component measured in the field with the use of this equipment was the remote sensing reflectance $\left(\mathrm{R}_{\mathrm{st}}\right)$, which, for its calculation, applies the following equation:

$R_{s r}=\frac{L_{u q}-f \cdot L_{d}}{E_{d}}$

Where $\mathrm{f}$ is a factor that varies with the size of the waves on the water surface. Generally, the value of 0.028 is adopted, as Mobley (1999) suggests.

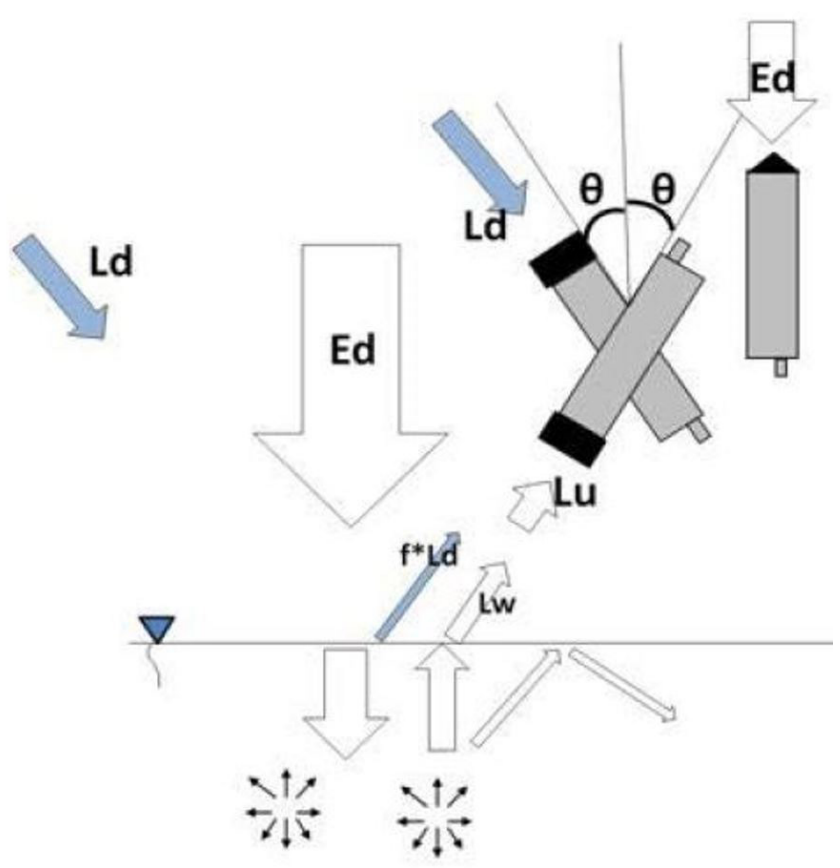

Figure 4. Reflectance measurement scheme by direct and simultaneous measurements method with three sensors measuring irradiance $\left(\mathrm{E}_{\mathrm{d}}\right)$, sky radiance $\left(\mathrm{L}_{\mathrm{d}}\right)$ and water radiance $\left(\mathrm{L}_{\mathrm{u}}\right)$, with $40^{\circ}<\Theta<45^{\circ}$. Source: Villar et al. (2012).

\section{Data correlation}

Suspended sediments are constituents that mainly cause the radiation scattering effect on the subsurface of water bodies (RUDORFF et al., 2007). The typical reflectance spectra of pure water points to a reduction of reflectance from $580 \mathrm{~nm}$, tending to zero from $700 \mathrm{~nm}$. As the sediments increase, an increase in reflectance is observed at all wavelengths, occurring with more intensity in the red and NIR regions (JENSEN, 2009).

The proposal of data integration to estimate the CSS from the satellite data involves correlation analysis between the $\mathrm{R}_{\mathrm{sr}}$ with the CSS values and the reflectance values measured by the orbital sensor (PINTO et al., 2014).

First, the CSS values obtained in field and laboratory data were correlated with the $\mathrm{R}_{\mathrm{sr}}$ measurements obtained by field spectroradiometry, which were used to simulate the reflectance measured by the orbital sensors. Each band of each sensor has different positions and widths, as well as different response functions of the detectors that comprise them. Figure 5 shows the band gain functions of the MODIS and Landsat 8 sensors.

The ideal reflectance simulation of a band is based on band gain (BAPTISTA, 2012). To simulate the bands in the present work, the equation 2 proposed by Rotta et al. (2016) was used.

$R_{r s s}=\frac{\sum R_{r s}(\lambda) * s(\lambda)}{\sum S(\lambda)}$

where:

$\mathrm{R}_{\mathrm{rss}}$ is the simulated reflectance for a given sensor; $\lambda$ is the wavelength; $\mathrm{R}_{\mathrm{rs}}$ is the in situ Reflectance measured by the spectroradiometer for a given wavelength of the spectral band; and $\mathrm{S}$ is the response function of the detectors that composes the band.

The simulated surface reflectance values for the sensors were correlated with the CSS data measured in the field. From the correlation curves we obtained regression equations that explain the relation between the reflectance and the CSS. These equations were applied to the historical series of MODIS surface reflectance images and Landsat-8 images using map algebra.

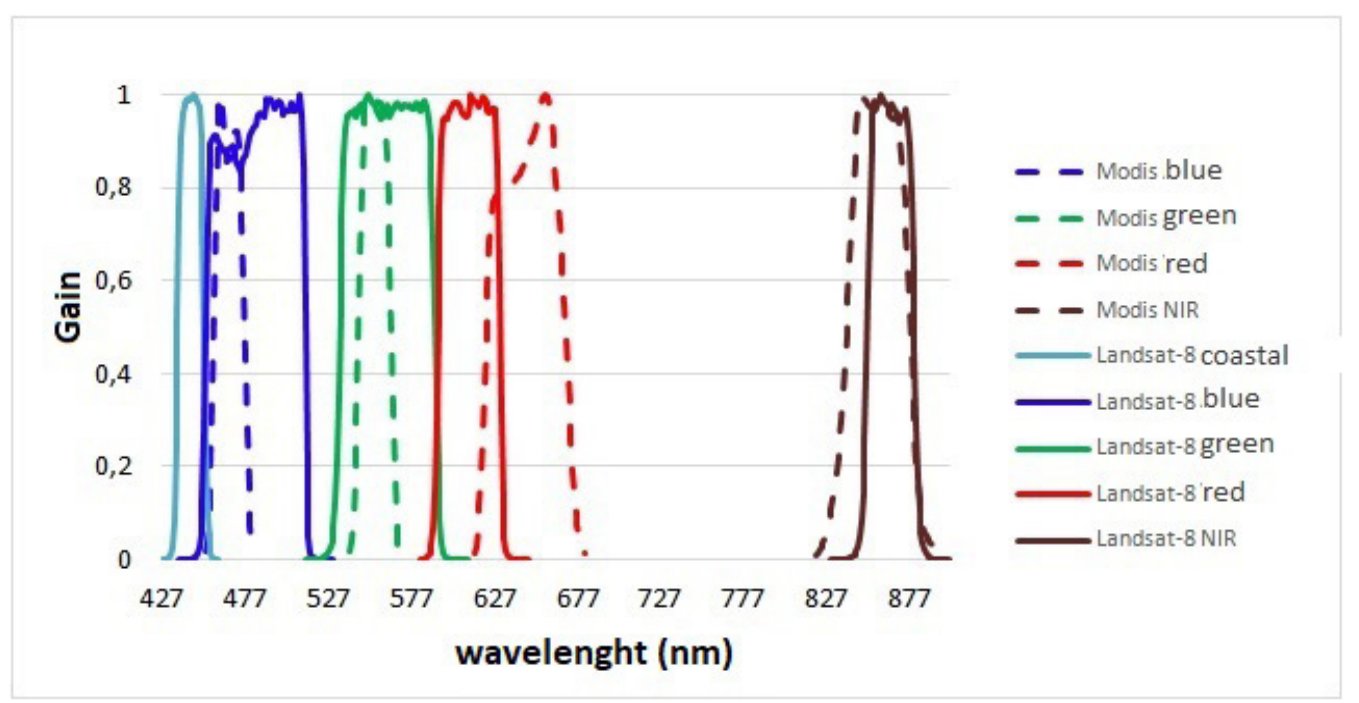

Figure 5. Band gain functions of MODIS and Landsat 8 Sensors in visible and NIR. Source: NASA. 


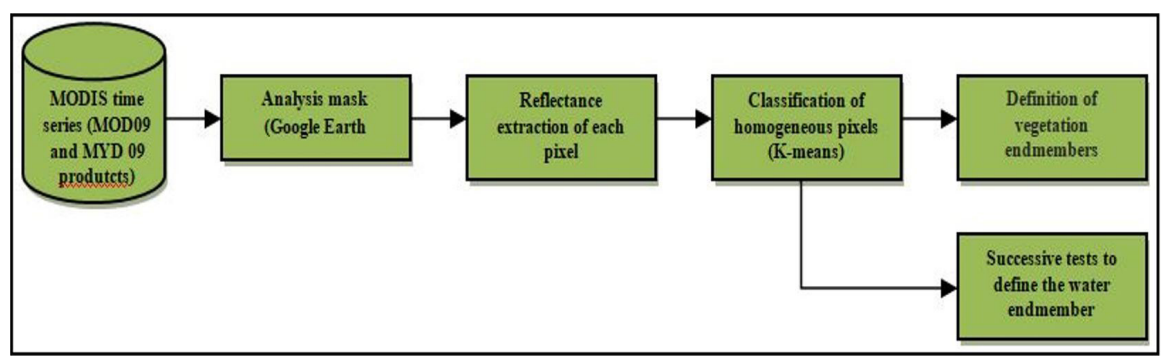

Figure 6. MOD3R processing flowchart. Source: Adapted from Pinto et al. (2014).

\section{Remote Sensing data processing}

For MODIS imagery, the products MOD09 and MYD09 of types A1 and Q1 were used: surface reflectance products in bands 1 to 7 used for various studies of the earth's surface. In addition to the estimation of surface reflectance for each pixel in each band, MOD09/MYD09 still presents quality data, such as integrity of the surface reflectance estimates; presence of clouds; if the pixel is land or water (ANDERSON et al., 2003). Each MOD09 or MYD09 pixel contains the best daily observation for 8-day intervals, selected based on the criterion of observation quality (low viewing angle, no clouds or cloud shadows, and low aerosol presence). The analysis interval of this work covers all images available between 2000 and 2017, comprising 18 years.

In order to obtain accurate spectral analysis of water, it is imperative to work exclusively with pure water pixels. To isolate these pixels, we used the MODIS River Reflectance Retrieval (MOD3R), developed by the IRD (2016) (Institute de recherche pour le developpement of France). This algorithm determines with precision and consistency over time the pure water pixels in an image, or its best candidates, regardless of the morphology types of the water bodies.

The MOD3R allows automatically process large number of images only by informing the area of interest in the image by selecting a mask. The methodology for extracting the water spectrum is presented in figure 6 .

In order to obtain all the images that compose the historical series, the software GETMODIS, also developed by the IRD, was used to acquire MOD/MYD09 A1 and Q1 products in HDF format in large quantities. The analysis mask was defined using the Google Earth software, in the approximate format of the water body or section of interest to be analyzed. Figure 7 shows the mask used in this work. The mask dimensions were defined as a function of the MODIS pixel size and the reservoir level variation, previously avoiding spectral mixtures.

First, the MOD3R analyzes the quality band product of MOD/MYD09A1 (500-meter spatial resolution), discarding the lower quality scenes and extracting the higher quality ones. Subsequently, the reflectance extraction of the pixels located inside the predefined masks is made. The reflectance values of the pixels are classified into homogeneous groups using the K-means statistical methodology (TOU; GONZALEZ, 1974).

The pixels estimation and classification in homogeneous groups is done as follows:

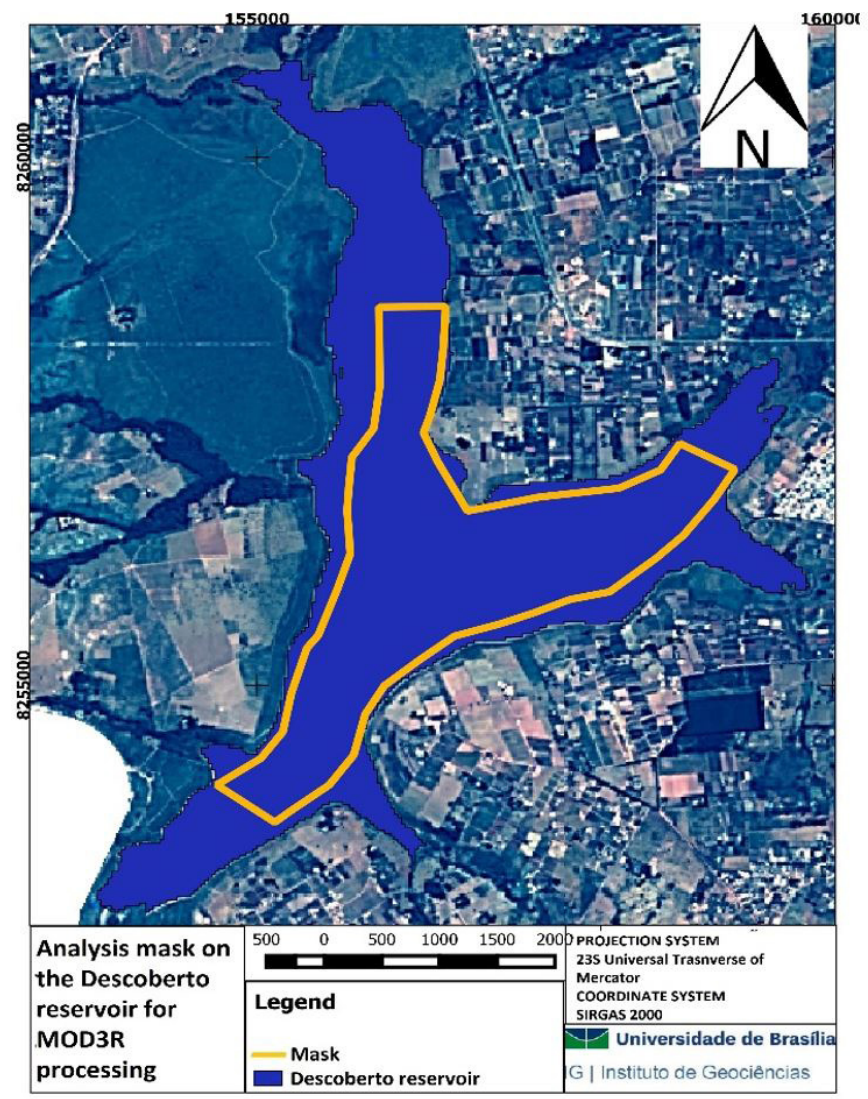

Figure 7. Analysis mask on the Descoberto reservoir for MOD3R processing, obtained by Google Earth software.

1. Random draw of $\mathrm{K} 1$ centroids;

2. Calculation of distance for each pixel to K centroids. Each pixel is assigned to the group whose distance is minimum in relation to all centroids;

3. Update centroids according to the new pixel group that forms the new group;

4. Repeat steps 2 and 3 until the satisfaction of a certain criterion of convergence.

At the end of the process we have $\mathrm{K}$ groups $\mathrm{Gi}$ with $1 \leq \mathrm{i} \leq \mathrm{K}$. Once the groups are defined, the one that best represents the water endmember is selected. 
For this, in the MODIS images the endmember of the vegetation is estimated directly by the maximum difference between the reflectance values of red and NIR bands. Finally, each group is tested as an endmember of water and the group of pixels that produces the smallest residual error is selected.

This procedure is repeated for each image of the time series and the reflectance values of bands 1 and 2 (red and NIR) of the pixels considered pure are returned in a table. To these images, the equation generated by the correlation curve was applied to obtain the values of CSS as a function of the reflectance measured by MODIS. In the case of Landsat 8 images, the CFmask band of the LaSRC product (Landsat 8 OLI Surface Reflectance Code) was used to obtain the pure water pixels.

LaSRC is obtained by the atmospheric correction process based on the radiative transfer model known as Second Simulation of the Satellite Signal in the Solar Spectrum Vectorial - 6SV (VERMOTE et al., 2006). This model uses the description of atmospheric properties from auxiliary data (eg, Rayleigh scattering, gaseous absorption) and aerosol concentration response using shorter wavelength bands (Blue). In this band of the electromagnetic spectrum the reflectance of the surface is generally small and the response of the aerosol is intense (VERMOTE et al., 2016).

CFmask is the band originally developed from the surface reflectance image to automate the identification of clouds, cloud shadows and snow for Landsat TM and ETM + images. This band identifies cloud pixels, cloud shadows, snow or water in the OLI surface reflectance product (USGS, 2016). The latter, used in this work.

Once the pure water pixels are defined in the reservoir, we apply the equation generated by the correlation curve to obtain the CSS values as a function of the reflectance measured by Landsat 8 .

\section{Validation}

In order to verify if the methods tested for the different sensors correctly estimated the CSS, the estimates were submitted to validation by comparison, either with the data collected during the field campaigns, or with the hydrological monitoring data of the Environmental Sanitation Company of Distrito Federal (CAESB).

CAESB has only one monitoring station in the Descoberto reservoir, which is located near the dam. At this point, water samples are collected once a month. However, discontinuity was observed in the collections, with several months during the analyzed period in which there was no collection or not all the parameters were calculated.

There is a lack in the historical series of CSS data, making comparison difficult. Most of the collection months present information on turbidity, but a few months present information on suspended solids. Since this parameter is highly related to CSS, and its values are comparable, allowing the use of this variable as an indirect measure of this parameter (SARI et al., 2015), the CSS estimates obtained from the MODIS sensor were also compared with turbidity for validate de model. Due to the absence of spatial coverage of the CAESB data, the validation of the CSS estimates from the Landsat 8 data were performed by comparing the CSS estimates obtained by the sensors with the values obtained from the samples collected in the field.

For the purposes of comparison, the root mean square error (\% RMSE) was calculated between the values estimated by the models and those measured in the field

\section{RESULTS AND DISCUSSION}

From the CAESB hydrological monitoring data, it is possible to observe the high relation between rainfall and turbidity, shown in figure 8 . The turbidity reaches its maximum in the middle of the rainy season and in the wettest month (January) of the historical series of rainfall, decreasing in the following months, following the seasonal behavior of the rains.

By analyzing the data of the history series, it is possible to observe that the turbidity accompanies the variation of the rainfall. Figure 9 shows the historical variation of rainfall and turbidity between the years 2000 and 2017.

The increase in rainfall leads to an increase in turbidity and, in general, the higher the rainfall, the greater the turbidity. The displacement to the right of the turbidity line indicates the time lapse between the rains and their respective effect on this parameter, measured in the dam. The discontinuity of the turbidity line occurs due to the absence of data collection in those months.

We detected two peaks with the highest turbidity. The first occurred in early 2004, when the Distrito Federal recorded the second highest rainfall for January $(420 \mathrm{~mm})$ since the beginning of the historical series of measurements at the BHAD in 1979, demonstrating the strong relationship between rainfall and

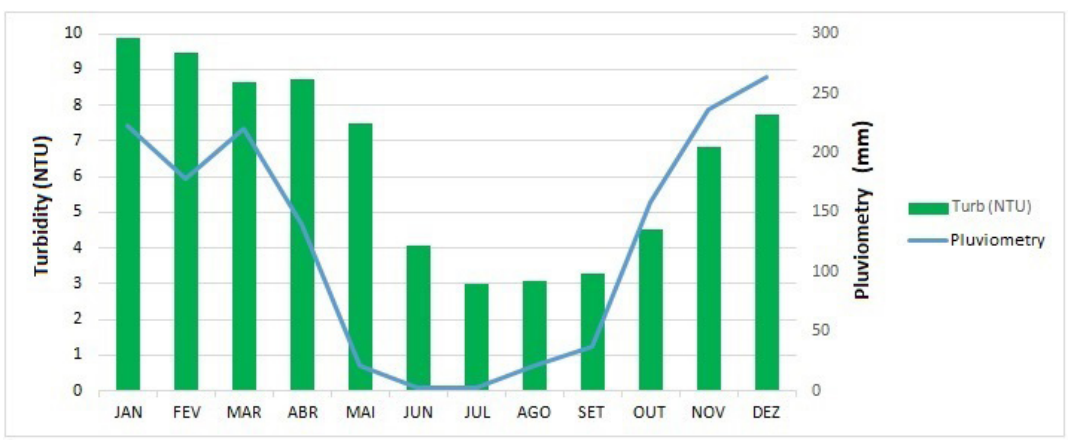

Figure 8. Seasonal behavior of turbidity and pluviometry in the Descoberto reservoir between 2000 and 2016. Source: CAESB and ANA. 


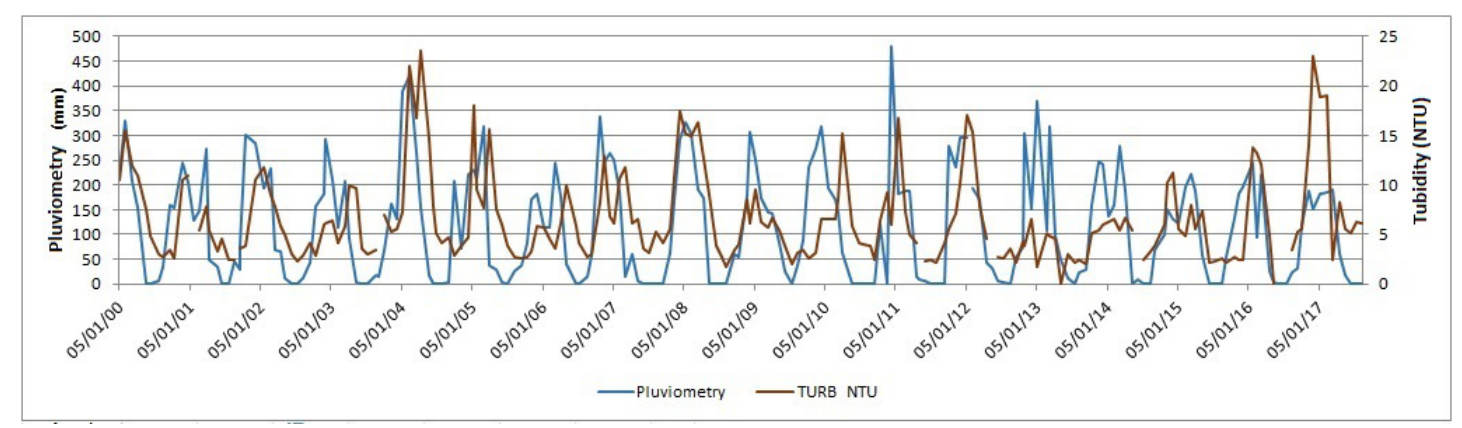

Figure 9. Temporal variation of Pluviometry and Turbidity in Descoberto reservoir between 2000 and 2017. Source: CAESB e ANA (2017).

sediment. And the second occurred at the beginning of 2017 , in which all the months of the rainy season (October 2016 to April 2017) presented rainfall below the historical average (ANA, 2017). The high turbidity in spite of the low rainfall in the last year can be explained by the low level of the reservoir in the period, when it reached its lowest levels already recorded (ADASA, 2017). Turbidity is not influenced only by rainfall. The reservoir level also interferes with the presence of sediment in the water. The lower the level of the reservoir at the time of rain, the greater the effect of this in the CSS.

\section{Measurement of suspended sediment concentrations from field collections}

Based on the data collected in the field and laboratory analyzes, the CSS was obtained in the eight points collected in each field campaign, presented in table 1.

At the end of the rainy season $(3 / 15 / 2016)$, the higher volume of water in the reservoir reduces the variability of the analyzed concentrations, making the lake homogeneous and with low sediment concentrations. At the beginning of the rainy season (9/10/2016), with the low level of the reservoir associated with the large volume of sediments carried by the first rains, the sediment concentration increases. There are more significant increases in the more massive inputs, such as the Descoberto river (Point 5), as well as those that suffer greater anthropic interference, such as the Coqueiro stream (Point 4), which receives discharges from the city of Águas Lindas/GO and the das Pedras stream (Point 7), which receives discharges from the city of Brazlândia/DF. In spite of this seasonal variability, the values of sediment concentration found in the Descoberto reservoir are considered low compared to other Brazilian reservoirs (PINTO et al., 2014; REGO, 2017), since CSS rarely exceeds $20 \mathrm{mg} / \mathrm{L}$ in this reservoir

\section{Optical properties of the Descoberto's reservoir waters}

The water reflectance depends on the components that are in the aquatic environment. Figure 10 shows the spectral behavior of each sampled spot in the reservoir and its respective CSS, performed in the laboratory from the field collections.
Table 1. CSS obtained from the field collections at eight points in the Descoberto reservoir.

\begin{tabular}{cccc}
\hline \multicolumn{4}{c}{ Suspended Sediment Concentration (mg/L) } \\
\hline Point & $\begin{array}{c}\text { Collection } \\
\text { in } \\
\mathbf{3 / 1 5 / 2 0 1 6}\end{array}$ & $\begin{array}{c}\text { Collection } \\
\text { in } \\
\mathbf{1 0 / 9 / 2 0 1 6}\end{array}$ & $\begin{array}{c}\text { Collection } \\
\text { in } \mathbf{4 / 2 8 / 2 0 1 7}\end{array}$ \\
\hline 1 (dam) & 7 & 4.2 & 3.2 \\
2 (Rocinha str.) & 8.4 & 7.2 & 3.9 \\
3 (Queimado str.) & 5.8 & 5.2 & 3.0 \\
4 (Coqueiro str.) & 6.2 & 11.2 & 3.1 \\
5 (Descoberto riv.) & 8.4 & 18 & 3.6 \\
6 (Rodeador str.) & 7.2 & 6.6 & 4.0 \\
7 (Das Pedras str.) & 6.8 & 13.6 & 4.2 \\
8 (center) & 6.4 & 4.2 & 3 \\
Means & 7.02 & 8.77 & 3.52 \\
\hline
\end{tabular}

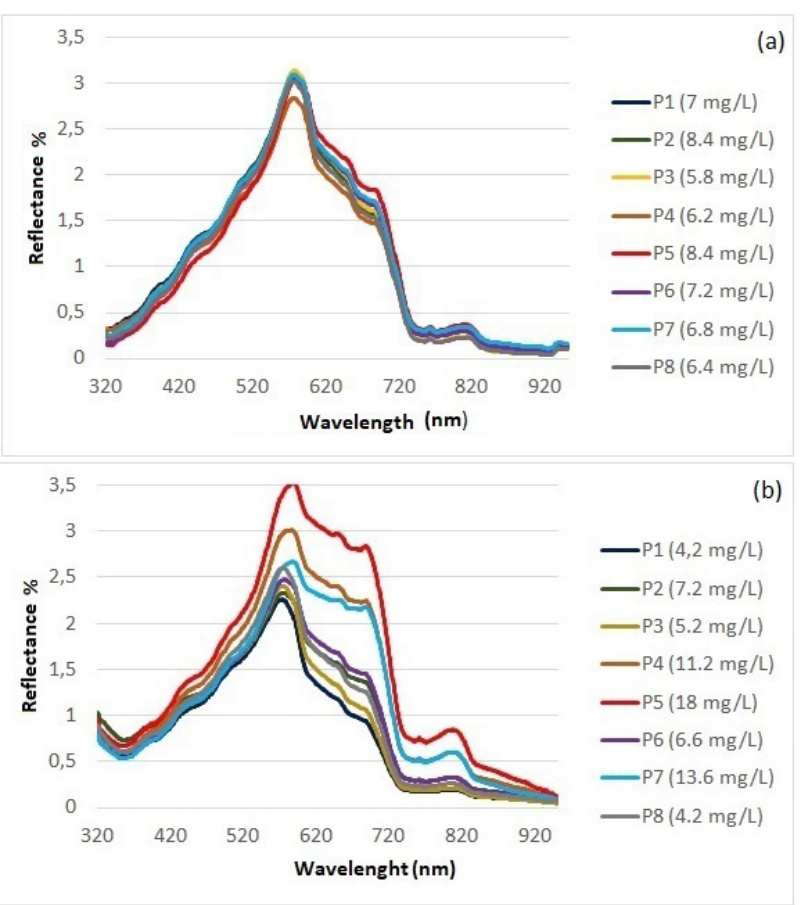

Figure 10. Spectral signatures and their respective CSS of the points sampled in the Descoberto reservoir on 3/15/2016 (a) and 10/9/2016 (b). 
It is possible to observe that the reflectance peak in all samples is in the green region (approximately $550 \mathrm{~nm}$ ). The peak in this range of the electromagnetic spectrum is typical of inland waters with low CSS, up to $100 \mathrm{mg} / \mathrm{L}$. As concentrations increase, the reflectance peak begins to shift towards the red and infrared bands (JENSEN, 2009).

The low reflectance values at the lowest wavelengths of the electromagnetic spectrum observed in all spectral signatures are due to the intense absorption in this band caused by the presence of dissolved organic matter (CDOM) (KIRK, 1994) and sediments.

By analyzing the spectral responses of the different points sampled in the Descoberto reservoir, it is possible to perform the spatial analysis of the CSS. In general, higher values of reflectance are observed in the entrance areas of the reservoir, especially points 4 (Coqueiro stream); 5 (Discovered river); 6 (Rodeador stream) and 7 (das Pedras stream), and lower values in the central zone and in the dam area (points 1 and 2).

The reflectance peaks at $580 \mathrm{~nm}$ in figure $10 \mathrm{a}$ and at $600 \mathrm{~nm}$ in figure $10 \mathrm{~b}$ indicate the shift of the spectrum from green to red as a result of increased CSS. The highest spectral variation is observed in the red region, between 620 and 690nm, where CSS has a strong influence on the spectral response. It is also possible to verify outstanding threshold formation in the $700 \mathrm{~nm}$ region and significant spectrum changes in the NIR region, where higher CSS also led to increases in reflectance, followed by abrupt reduction of reflectance until reaching zero in the mean infrared. In the regions of blue and green, the sediment increment did not alter the spectral response, indicating little influence of these bands on the spectral behavior.

By the analysis of the graphs it is possible to perceive greater homogeneity of the reservoir at the end of the rainy season (Figure 10a). The spectral curves of the 8 points sampled are similar and the variance of the CSS is lower (0.92). At the beginning of the rainy season (Figure 10b), we observe significant differences between the spectral curves, mainly in the red and NIR regions, indicating greater variability in CSS along the reservoir, a fact also observed by the higher variance of CSS in this period $(25,16)$. The reflectance peaks in the regions of red demonstrate the existence of a direct relation between the reflectance in this region of the electromagnetic spectrum and the CSS.

Although the spectral responses in the NIR region are also influenced by CSS, the NIR bands of MODIS and Landsat 8 also receive a greater adjacency contribution of the neighboring pixels in comparison to the red band. Adjacency effects are optical-physical processes caused by molecular dispersion and aerosols, where the target's vision is affected by the radiation reflected on the surrounding surfaces (TANRE et al., 1981). In inland waters, these effects are more evident due to their lower reflectance to nearby surfaces, such as vegetation around reservoirs (STERCKX et al., 2015).

As the surroundings of the Discover reservoir are basically covered by vegetation, the high contrast of spectral response between vegetation and water surfaces contributes to spectral distortions of water pixels closer to the edge. This effect is more intense in the NIR band (MARTINS et al., 2017).

This phenomenon contributed to overestimation in the NIR band. Thus, the red band was more adequate for the estimation of CSS in the Descoberto reservoir.

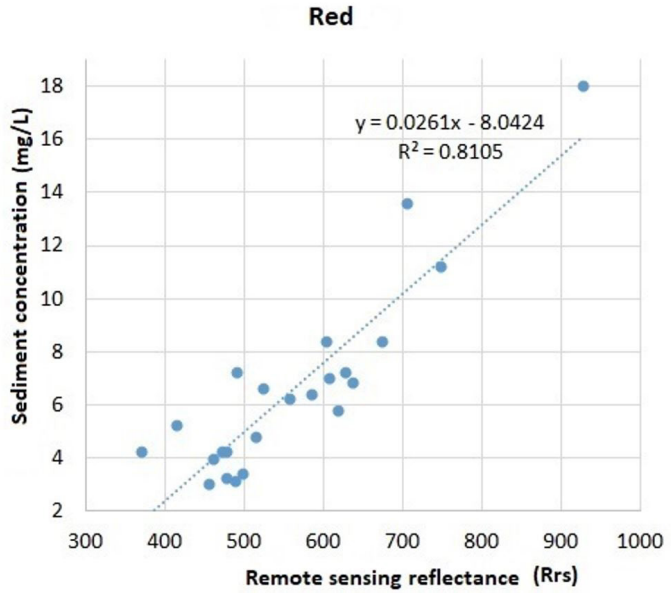

Figure 11. Correlation of the $\mathrm{R}_{\mathrm{rs}}$ of the red band of the MODIS data with the CSS measured in the field.

\section{Temporal analysis of suspended sediment concentration based on MODIS data}

We processed 1339 images with the MOD3R algorithm, being selected 589 by the quality criteria. From these, the surface reflectance of the water was extracted. Figure 11 shows the correlation graph between the CSS measured in the field and the $\mathrm{R}_{\mathrm{rs}}$ in the red band of the MODIS satellites.

The correlation between these parameters generated equation 3 , whose coefficient of determination $\left(\mathrm{R}^{2}\right)$ was 0.8105 , considered satisfactory when compared to the sediment estimates equations found in the literature review performed by Chen et al. (2015).

$$
C S S=0,0261 * B 1-8,0424
$$

where:

CSS is the suspended sediments concentration and B1 is the surface reflectance value of the red band of the MODIS data.

For validation purposes, this model was applied to the MODIS time series and compared to the historical turbidity series produced by CAESB, as well as to the historical CSS series obtained through the correlation between turbidity and CSS from the field data.

Figures 12 and 13 present the time series of CSS in the Descoberto reservoir from MODIS data, compared to turbidity measured over the same period, and CSS, respectively. The blue dots refer to CAESB measurement days. The dots in red refer to days on which this measurement occurred on exactly the same day as the obtainment of a MODIS scene used in the time series.

The model was able to capture the seasonal variation of CSS: higher in the rainy months (October to April) and lower in the dry season (May to September). The estimated CSS values were close to the turbidity values. The RMSE \% found was 39.91\%. This error refers to the tendency of overestimation of the model, which can be explained by the following factors.

The first is the adjacency contribution phenomenon, explained in the previous topic. Given the spatial resolution of $250 \mathrm{~m}$ of MODIS band 1, the area affected by this contribution becomes significant in relation to the total area of the mask. 


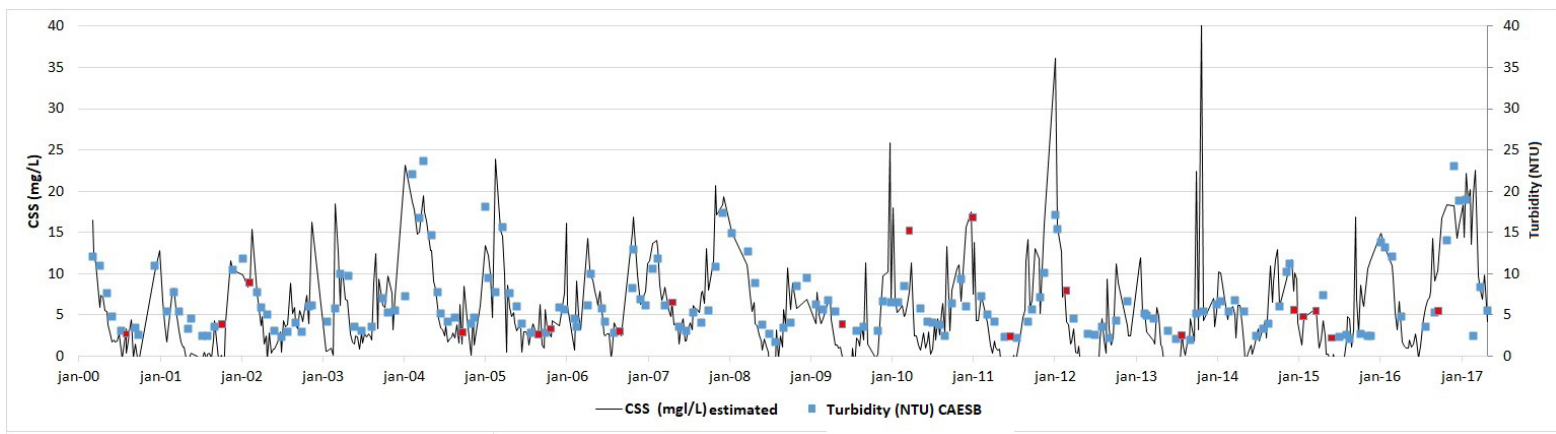

Figure 12. Temporal variation of CSS, based on MODIS data, and CAESB NTU turbidity between 2000 and 2017.

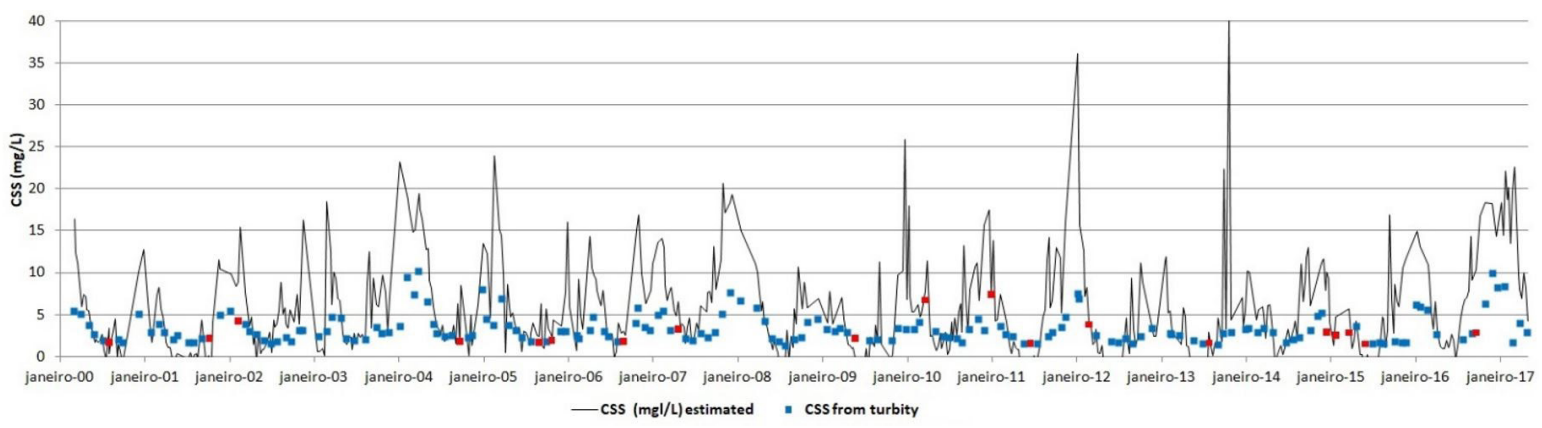

Figure 13. Temporal variation of CSS, based on MODIS data, and CSS from turbidity data, between 2000 and 2017.

As MOD3R returns only a surface reflectance value for all the pure water pixels inserted in the mask, this effect contributes to the increase of the mean value of reflectance and, consequently, contributes to the overestimation of the CSS.

The second is the fact that a single mask has been applied to the reservoir, causing the edge pixels with higher reflectance to raise the average value of the CSS. Due to the reduced size of the reservoir as well as the seasonal variation of the dimension and considering the MODIS pixel size, it was only possible to use a single mask instead of different masks for the different sections of the reservoir, that would improve the accuracy of the estimates.

The third factor is the difference in location between collection sites. The CSS values used in the validation are obtained from the dam (Figure 4, point 1), where the turbidity is lower and, consequently, the corresponding CSS. The CSS values estimated from equation 3 reflect the average CSS of the reservoir.

Rego (2017), when analyzing several CSS estimation models in inland waters, observed that most models for water bodies with low CSS (CSS $\leq 100 \mathrm{mg} / \mathrm{L}$ ) presented RMSE \% higher than 30\%, possibly due to the lower variation in these waters.

Considering the factors that lead to the overestimation tendency of the model and its adjustment in relation to turbidity and CSS, presented in Figures 12 and 13, it is possible to determine a safe limit of CSS estimation from equation 3. The range between 400 and $1000 \mathrm{R}_{\mathrm{rs}}$ surface reflectance denotes adequate sensor ability to detect variations in sediment concentrations, even in low concentration waters.

From the time series obtained it was possible to determine the seasonal behavior of the sediment concentration of the Descoberto reservoir and to relate it to the climate. Figure 14

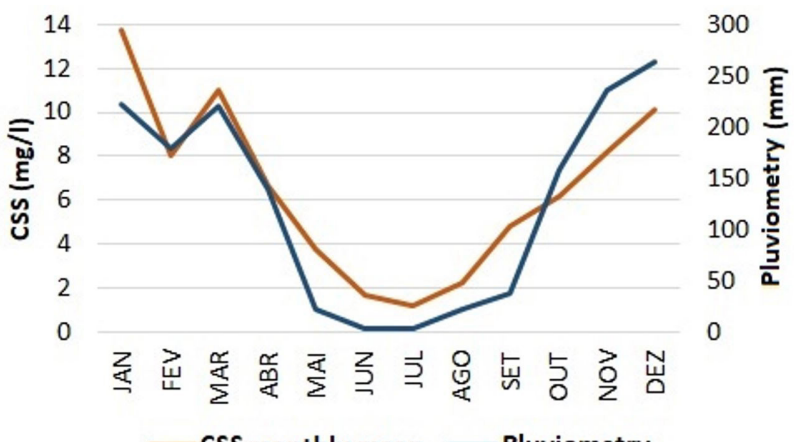

Figure 14. Seasonal CSS behavior in the Descoberto reservoir and its association with rainfall.

presents a comparison betwen the monthly means of CSS of the Descoberto reservoir and rainfall.

We observed that the CSS is directly influenced by rainfall, given the similarity between the two curves. We highlight the phenomenon of sediment return occurred in the month of March, which can be explained by lower rainfall in the month of February compared to March.

The strong relationship between rainfall and sediment concentration also explains the sediment concentration peaks observed in Figures 12 and 13. These peaks occurred due to historical rains occurring in the periods. Table 2 shows the CSS events greater than $20 \mathrm{mg} / \mathrm{L}$ and the rainfall of the 10 days prior to these events. 
Tabela 2. Peaks of sediment concentration and associated rainfall.

\begin{tabular}{cccc}
\hline Date of the event & Estimated CSS (mg/L) & $\begin{array}{c}\text { Pluviometry of the previous } \\
\text { 10 days (mm) }\end{array}$ & $\begin{array}{c}\text { Equivalent percentage of } \\
\text { rain expected for the month }\end{array}$ \\
\hline $01 / 26 / 2004$ & 23.15 & 172.7 & 77.47 \\
$03 / 06 / 2005$ & 23.95 & 249.1 & 112.9 \\
$11 / 17 / 2007$ & 20.65 & 82.8 & 39.68 \\
$01 / 09 / 2010$ & 25.90 & 102.3 & 45.89 \\
$01 / 25 / 2012$ & 36.09 & 200.3 & 89.86 \\
$11 / 09 / 2013$ & 40.35 & 97.3 & 41.24 \\
$02 / 10 / 2017$ & 22.13 & 91.8 & 46.93 \\
$03 / 22 / 2017$ & 22.55 & 78.8 & 38.42 \\
\hline
\end{tabular}

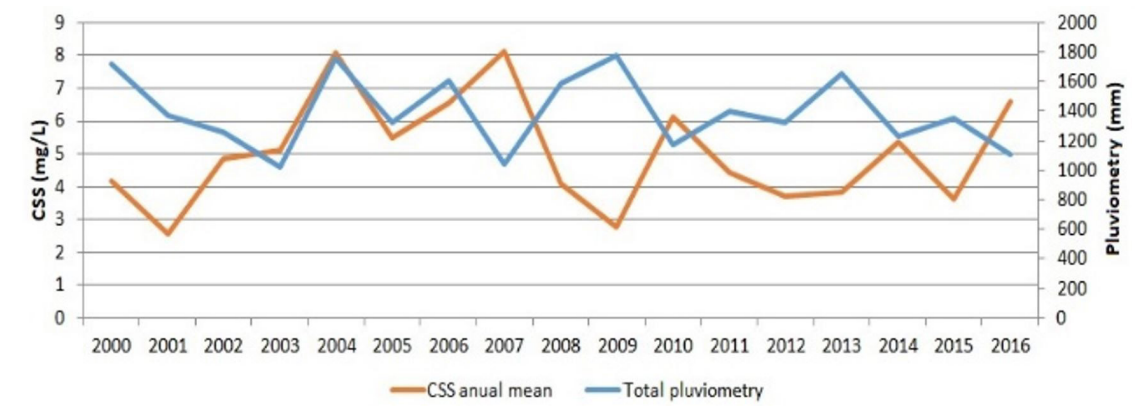

Figure 15. Variation of annual mean CSS and annual total rainfall between 2000 and 2016 at the Descoberto reservoir. Source: ANA (2017).

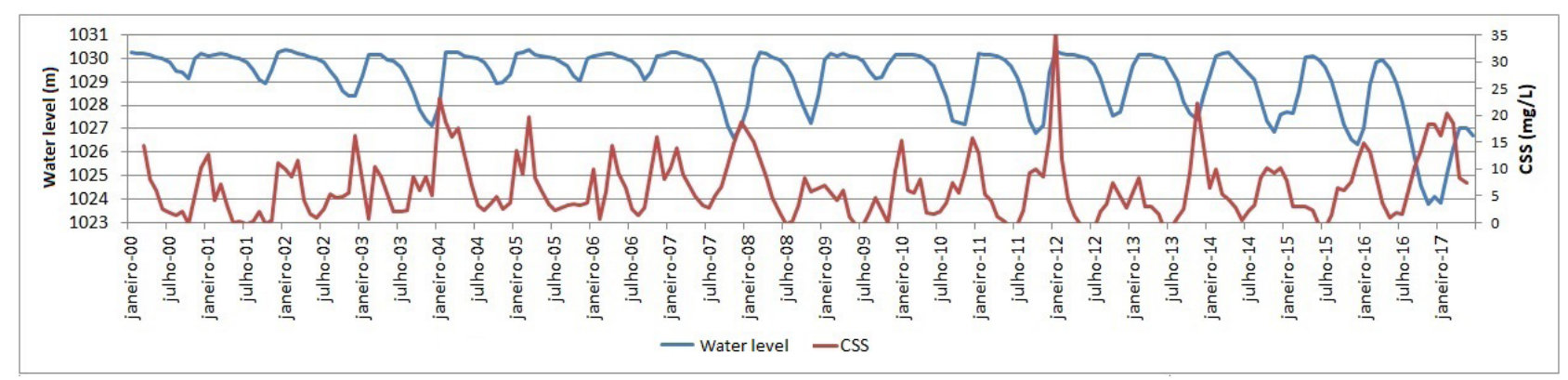

Figure 16. Variation of CSS and quota between 2000 and 2017 in the Descoberto reservoir. Source: ANA (2017).

In all events it rained more than expected for the period, significantly increasing the sediment concentration. In the case of CSS peaks of the dates $17 / 11 / 2007 ; 09 / 11 / 2013 ; 10 / 02 / 2017$; and $22 / 03 / 2017$, in spite of the fact that rainfall was not much higher than expected for the period, the level of the reservoir was lower. The first two were the beginning of the rainy season where the first rains carry more sediments and the reservoir historically is in its smaller annual level. The last two occurred during the strong water crisis that occurred in the Federal District since 2016, resulting in the lowest levels already recorded for the Descoberto reservoir (ANA, 2017). In this way, we observed that not only the amount of rain, but its time in relation to the beginning of the rainy season and the level of the reservoir also influence the sediment concentration.

This phenomenon is expected, since, in smaller reservoirs, external events of reduced magnitude should provide greater changes in the physical, chemical and biological characteristics of the water body than this same event acting in larger reservoirs (THORNTON, 1990).
The high influence of rainfall on CSS in the Descoberto reservoir can also be explained by the high Circularity Index - CI of the BHAD, approximately 0.6. The closer to 1.0 the CI, the more circular is the basin. The more circular the basin, the faster the effects of a rainfall are perceived in the basin output (LIMA, 2008; FREVERT et al., 1963).

From the time series of CSS generated by MODIS, there was a trend of a slight increase of sediments over the 18 years of the historical series analyzed, with an increase of approximately $1.3 \mathrm{mg} / \mathrm{L}$ in the annual mean CSS over the analyzed period, equivalent to an average annual increase of approximately $0.08 \mathrm{mg} / \mathrm{L}$. This corresponds to an increase of approximately $20 \%$ of sediments over the analyzed period. However, this increase does not occur regularly over the years.

There is great variation in the mean annual concentration of suspended sediments in the reservoir in the historical series analyzed in this work. Figure 15 shows the mean annual CSS variation between 2000 and 2016, from the MODIS data, and the annual rainfall of the period. 
It is also possible to observe a subtle tendency of precipitation decrease in the BHAD throughout this series. One of the factors that can explain the tendency of increase of CSS in spite of the tendency of precipitation decrease is the increase of the variation of the level of the reservoir verified in the last years, causing a greater revolving of the bottom of the reservoir, suspending sediments.

Figure 16 shows the variation of CSS and reservoir level between 2000 and 2017. We observe a change in the annual variation pattern of the reservoir quota between the first years of the historical series and the last ones. In the years of higher quota variation, higher CSS is also observed. This relationship is evidenced by the emptying and flood events between 2003 and 2004; 2007 and 2008; 2011 and 2012; 2013 and 2014; 2016 and 2017, when the concentrations exceeded $20 \mathrm{mg} / \mathrm{L}$ as a result of more pronounced quota variations on the order of 3 meters.

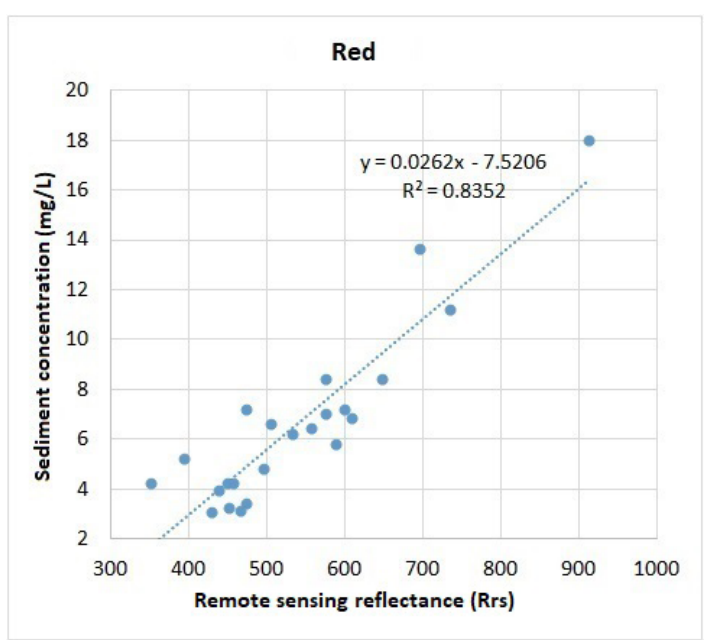

Figure 17. Correlation of red band $\mathrm{R}_{\mathrm{rs}}$ of the OLI sensor with the measured CSS in the field.
The change in reservoir behavior may be related to the territorial occupation of the Distrito Federal, and especially to the BHAD. The reduction of rainfall, coupled with the intensification of water pullout to supply the population of the Distrito Federal, caused the most intense variation of the lake quota in recent years. The greater amount of soil exposed in the reservoir, caused by this variation, increases the sediments resuspension phenomenon when rains occur, increasing the CSS.

\section{Spatial analysis of suspended sediment concentration based on Landsat - 8 data}

The correlation between the concentrations obtained in the field and the $\mathrm{R}_{\mathrm{rs}}$ of the red band (B4) of the LaSRC is shown in figure 17 , which generated equation 4 , whose $R^{2}$ was 0.8352 .

$$
\text { CSS }=0,0262 * B 4-7,5206
$$

where:

B4 is the reflectance value of the OLI sensor red band.

We observed that equations 3 and 4 are similar, because both surface reflectance products are provided by the United Estates Geological Service - USGS and have similar atmospheric correction algorithms and share the same auxiliary data for the generation of surface reflectance images (VERMOTE et al., 2006; USGS, 2016; VERMOTE et al., 2016).

For validation, the model proposed by equation 4 was applied to the surface reflectance images of 3/15/2016 and 10/09/2016, field collection dates, and compared with the estimated CSS in the pixel closest to the collection point. Figure 18 shows the spatial distribution of sediment concentrations from the Landsat- $8 \mathrm{R}$ data for these 2 dates. The blank areas in Figure 18a are "no-data" values due to the presence of clouds, taken out by the CFMask application. However, the blank areas inside the reservoir in

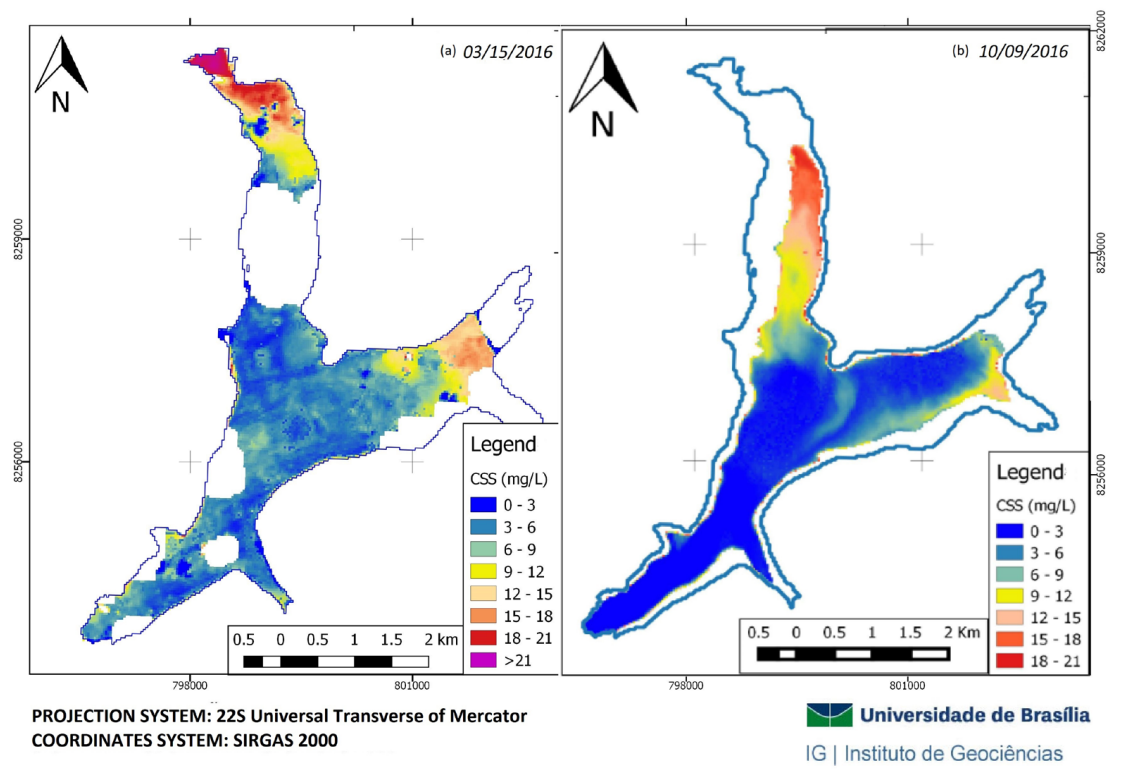

Figure 18. CSS spatial distribution in the Descoberto reservoir on 3/15/2016 (a) and 10/9/2016 (b), based on the simulated red band of the OLI sensor. 


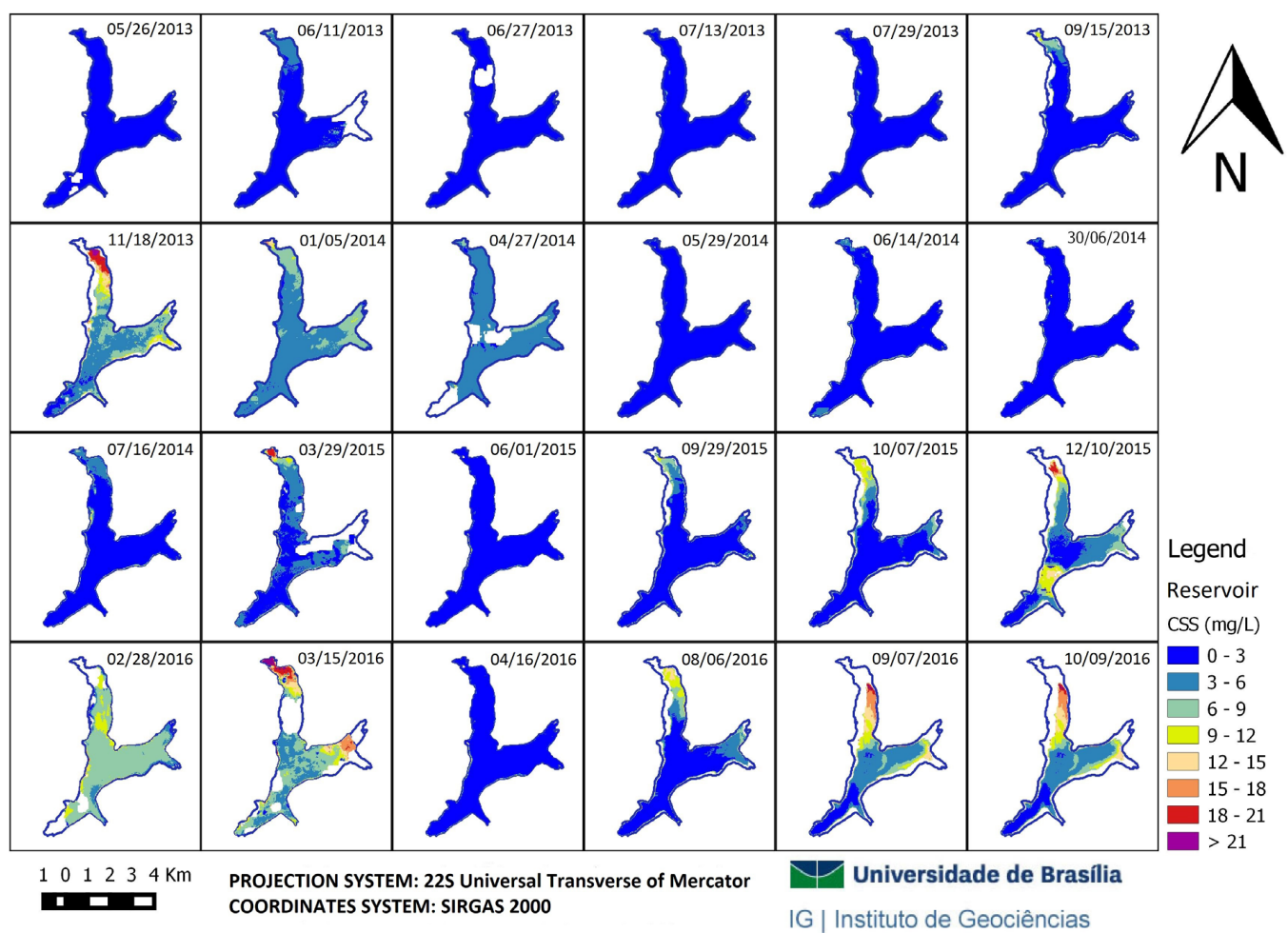

Figure 19. Spatial behavior of CSS between May 2013 and October 2016 from Landsat data 8.

Figure $18 \mathrm{~b}$ are areas where no pure water pixels occurred because of the low reservoir level.

The model proposed by equation 4 proved to be a good CSS estimator, presenting values quite consistent with those verified in the field, by correctly capturing the spatial distribution pattern of CSS along the reservoir. The RMSE \% for the model of equation 4 was $15.12 \%$, presenting high precision given the great similarity between the data estimated and effectively measured in the field.

Once the model has been validated, it can be applied to the collection of Landsat 8 images. As these images only became available from 2013, 82 images were obtained between 4/24/2013 and $12 / 28 / 2016$, of which 24 were selected mainly because of the atmospheric quality, presence of clouds, aerosols and mist. From the analysis of these images it is possible to analyze the spatial behavior of the sediment concentration over time. Figure 19 shows the evolution of the spatial behavior of CSS in the Descoberto reservoir at different dates.

From the analysis of the images, it is noticed that the section that receives the highest sediment load throughout the year is the Descoberto river, also being the one that suffers the greatest variation of CSS. The ones that receive lower loads are the Rocinha and Queimado streams. In the section next to the dam, where the pumping of water for supply is carried out, the sediment concentration remains practically stable throughout the year. Similar behavior is also seen in the central portion of the reservoir. The pattern of higher CSS in the entrance areas of the reservoir, decreasing as it approaches the output, is typical of reservoirs and large rivers, being found by Pinto et al. (2014), Villar et al. (2012), Santini et al. (2014).
Figure 19 also allows space-time analysis of CSS in the Descoberto reservoir. It is observed a homogeneous lake and with very low sediment concentrations in the months of drought (May to September). In the images of the rainy season the lake is more heterogeneous, with higher concentrations in the entrance areas decreasing towards the dam. As the reservoir fills up, at the end of the rainy season, the CSS decreases and the lake homogenizes again, completing its cycle.

\section{CONCLUSION}

This study represents a complete work on the variability of the sediment concentration in small reservoirs focused on human supply in long term, seasonal and spatial scales.

The surface reflectance products MOD09 / MYD09 and Landsat 8 are efficient for the analysis of suspended sediments in waters with low concentrations due to their high correlation between the sensor data and those obtained by field spectroradiometry. The similarity between the equations of the two CSS estimation models presented in this study indicates the similarity of the radiometric adjustment of these sensors and, consequently, their potential for integrated use of the data in other studies.

Given its spatial resolution, Landsat 8 allows detailed analysis of the spatial behavior of suspended sediments, formation of plumes and zones of higher contribution, even in reservoirs with little variation of CSS. Despite the lower temporal resolution of the Landsat- 8 satellite compared to MODIS, it is possible to make the adequate space-time analysis of small reservoirs, considering that approximately 22 sensor passages occur per year. This set 
of characteristics ensures that the methodology presented here is replicable in reservoirs with similar characteristics.

The optical properties of the water indicate the red region of the electromagnetic spectrum as the one with the highest potential for CSS estimation, since it is the range with the highest spectral variation as a function of the variation of the CSS.

\section{ACKNOWLEDGEMENTS}

We thank CAESB, ANA and ADASA for providing hydrological data that support this work; to the IRD/FR for the development of software fundamental to the development of research; and the Aquasense/FINEP Project for funding the research.

\section{REFERENCES}

ADASA - AGENCIA REGULADORA DE ÁGUAS, ENERGIA E SANEAMENTO BÁSICO DO DISTRITO FEDERAL. Nota Técnica $n .^{\circ}$ 58/2016. Brasília: SRH/ADASA, 2016. Disponível em: http://www.adasa.df.gov.br/images/stories/anexos/3Cons umidor/2AudienciasPublicas/2016/AP005-2016/NTn582016_ simulacaoDescobertoSISGED5011.pdf. Acesso em: 07 fev. 2017.

ADASA - AGENCIA REGULADORA DE ÁGUAS. ENERGIA E SANEAMENTO BÁSICO DO DISTRITO FEDERAL. Níveis dos Reservatórios de Santa Maria e Descoberto. Disponível em: < http://www.adasa.df.gov.br/monitoramento/niveis-dereservatorios/historico>. Acesso em: 8 mar. 2017

ANA - AGÊNCIA NACIONAL DE ÁGUAS. Gestor PCD - Sala de situação. 2017. Disponível em: http://gestorpcd.ana.gov.br/ Mapa.aspx Acesso em: 1 abril 2017.

ANDERSON, L. O.; LATORRE, M. L.; SHIMABUKURO, Y. E.; ARAI, E.; CARVALHO JÚNIOR, O. A. Sensor MODIS: uma abordagem geral. São José dos Campos: INPE, 2003

APHA - AMERICAN PUBLIC HEALTH ASSOCIATION. Standard methods for the examination of water and wastewater. 20. ed. New York: APHA/WWA/WPCR, 1998.

BAPTISTA, G. M. M. Processamento de dados hiperespectrais. In: MENESES, P. R.; ALMEIDA, T. (org). Introdução ao processamento de imagens de sensoriamento remoto. Brasília: CNPq, 2012. 266 p.

BESKOW, S., TIMM, L. C., TAVARES, V. E. Q., CALDEIRA, T. L., AQUINO, L. S. Potential of the LASH model for water resources management in data-scarce basins: a case study of the Fragata River basin, southern Brazil. Hydrological Sciences Journal, v. 61, n. 14. 2016. http://dx.doi.org/10.1080/02626667.2015.1133912

CHALOV, S. R.; BAZILOVA, V. O.; TRASOV, M. K. Modelling suspended sediment distribution in the Selenga River Delta using LandSat data. Proc. IAHS, 375, 19-22, 2017. http:/ /dx.doi. org/10.5194/piahs-375-19-2017.
CHEN, S.; HAN, L.; CHEN, X.; LI, D.; SUN, L.; LI, Y. Estimating wide range Total Suspended Solids concentrations from MODIS 250-m imageries: An improved method. ISPRS Journal of Photogrammetry and Remote Sensing, v. 99, p. 58-69, 2015. http:// dx.doi.org/10.1016/j.isprsjprs.2014.10.006.

DISTRITO FEDERAL. Adequação Ambiental da Reserva Biológica e das Propriedades Rurais às Margens do Lago Descoberto. Brasília: 2009, 87 f. Disponível em: < http:/ /www.descobertocoberto.df.gov.br/ documentos/AdequacaoAmbiental_VersaoFinal.pdf $>$. Acesso em: 24 set. 2015.

DUARTE, C. R.; CORDEIRO, E. F.; ARAUJO DA COSTA, J. H. B.; SABADIA, J. A. B.; SALGUEIRO, A. R.; SOUTO, M. V. S.; SILVA FILHO, W. F. Principal component analysis and morphostructural characterization of a portion of the eastern continental shelf of Ceará, Brazil, using Landsat 5-TM images. Journal of Sedimentary Environments, v. 1, n. 3, p. 324-333, 2016. http://dx.doi.org/10.12957/jse.2016.25905.

FREVERT, R. K.; SCHWAB, G. O.; EDMINSTER, T. W.; BARNES, K. K. Soil and water conservation and engeneering. New York: John Wiley e sons, Inc., 1963. 493 f.

GERACE, A. D., SCHOTT, J. R., NEVINS, R. Increased Potential to Monitor Water Quality in the Near-shore Environment with Landsat's next-generation satelite. Journal of Applied Remote Sensing, v. 7, 2013. $19 \mathrm{f}$.

HORTON, R. E. Drainage basin characteristics. Transactions American Geophysical Union, v. 13, n. 1, p. 350-361, 1932. http:/ / dx.doi.org/10.1029/TR013i001p00350.

IRD - INSTITUTE DE RECHERCHE POUR LE DEVELOPPEMENT. MODIS River Reflectance Retrieval (MOD3R). Disponível em: <http://www.ore-hybam.org/index. php/eng/Software/Getmodis-Mod3r>. Acesso em: 05 mar. 2016.

JENSEN, J. R. Sensoriamento Remoto do ambiente: uma perpectiva em recursos terrestres. São José dos Campos: Parêntese, 2009. tradução José Carlos Neves Epiphanio (coord.). 598 p.

KIRK, J. T. O. Light and phtosynthesis in aquatic ecosystems. Cambridge: Cambridge University Press, 1994. http://dx.doi.org/10.1017/ CBO9780511623370.

KO, N. T.; RUTTEN, M.; CONALLIN, J. Remote Sensing Analysis of Temperature and Suspended Sediment Concentration in Ayeyarwady River in Myanmar. Global Journal of Engineering and Technology Review., v. 2, n. 3, p. 30-47, 2017.

KÖPPEN, W. Climatalogía: con un studio de los climas de la Tierra. México: Fondo de Cultura Económica, 1948. 172 f.

LILLESAND, T. M.; JOHNSON, W. L.; DEUELL, R. L.; LINDSTROM, O. M.; MEISNER, D. E. Use of Landsat data to predict the trophic state of Minnesota lakes. Photogrammetric Engineering and Remote Sensing, v. 49, p. 219-229, 1983. 
LIMA, W. P. Hidrologia florestal aplicada ao manejo de bacias hidrográficas. Piracicaba: ESALQ/USP, 2008. 245 f.

MANZO, C.; BRAGA, F.; ZAGGIA, L.; BRANDO, V. E.; GIARDINO, C.; BRESCIANI, M.; BASSANI, C. Spatiotemporal analysis of prodelta dynamics by means of new satellite generation: the case of Po river by Landsat-8 data. Int J Appl Earth Obs Geoinformation, v. 66, p. 210-225, 2018. http://dx.doi. org/10.1016/j.jag.2017.11.012.

MARKET, K. N.; SCHIMT, C. M.; GRIFFIN, R. E.; FLORES, A. I.; POORTINGA, A.; SAAH, D. S.; MUENCH, R. E.; CLINTON, N. E.; CHISHTIE, F.; KITYUTTACHAI, K.; SOMETH, P.; ANDERSON, E. R.; AEKKAPOL AEKAKKARARUNGROJ, A.; GANZ, D. J. Historical and operational monitoring of surface sediments in the lower mekong basin using landsat and Google Earth engine cloud computing. Remote Sensing, v. 10, p. 909, 2018. http://dx.doi.org/10.3390/rs10060909.

MARTINEZ, J.-M.; ESPINOZA-VILLAR, R.; ARMIJOS, E.; SILVA MOREIRA, L. The optical properties of river and floodplain waters in the Amazon River Basin: Implications of satelite-based measurements of suspended particule matter. Journal of Geophysical Research. Earth Surface, v. 120, n. 7, p. 1274-1287, 2015. http:// dx.doi.org/10.1002/2014JF003404.

MARTINS, V. S.; BARBOSA, C. C. F.; CARVALHO, L. A. S.; JORGE, D. S. F.; LOBO, F. L.; NOVO, E. M. L. M. Assessment of Atmospheric Correction Methods for Sentinel-2 MSI Images Applied to Amazon Floodplain Lakes. Remote Sensing, v. 9, n. 4, p. 322, 2017. http://dx.doi.org/10.3390/rs9040322.

MOBLEY, C. D. Estimation of the remote-sensing reflectance from above surface measurements. Applied Optics, v. 38, n. 36, p. 7442-7455, 1999. http://dx.doi.org/10.1364/AO.38.007442. PMid:18324298.

MONTANHER, O. C.; SOUZA FILHO, E. E. Estimating the suspended sediment concentration in the upper Paraná river using LANDSAT 5 data: data retrieval on a large temporal scale and analysis of the effects of damming. Geografia. v. 40, n. 1, jan./ abr. 2015.

MÜLLER, V.C. A quantitative geomorphology study of drainage basin characteristic in the Clinch Mountain Area, New York, Virginia and Tennesse. Department of Geology, n. 3, p. 30, 1953.

OYAMA, Y.; MATSUSHITA, B.; FUKUSHIMA, T.; MATSUSHIGE, K.; IMAI, A. Application of spectral decomposition algorithm for mapping water quality in a turbid lake (Lake Kasumigaura, Japan) from Landsat TM data. ISPRS Journal of Photogrammetry and Remote Sensing, v. 64, n. 1, p. 73-85. 2009.

PINTO, C. E. T.; MENEZES, P. H. B. J.; MARTINEZ, J. M.; ROIG, H. L.; VILLAR, R. A. E. Uso de Imagens MODIS no monitoramento do fluxo de sedimentos no reservatório de Três Marias. Revista Brasileira de Engenharia Agrícola e Ambiental, v. 18, n. 5, p. 507-516, 2014. http://dx.doi.org/10.1590/S141543662014000500007.

REGO, I. S. Variabilidade das Propriedades Óticas Aparentes de Águas Continentais por Meio de Sensores Hiperespectrais para o Monitoramento da Qualidade das Águas. 2017. 113 f. Dissertação (Mestrado) Universidade de Brasília, Instituto de Geociências, Brasília, 2017.

ROTTA, L. H. S., ALCÂNTARA, E. H., WATANABE, F. S. Y., RODRIGUES, T. W. P., IMAI, N. N. Atmospheric correction assessment of SPOT-6 image and its influence on models to estimate water column transparency in tropical reservoir. Remote Sensing Applications: Society and Environment, v. 4, p. 158-166. 2016.http://dx.doi.org/10.1016/j.rsase.2016.09.001

RUDORFF, B. F. T.; SHIMABUKURO, Y. E.; CEBALLOS, J. C. O Sensor MODIS e suas Aplicaçoes Ambientais no Brasil. São José dos Campos: Editora Parêntese, 2007.

SANTINI, W.; MARTINEZ, J. M.; VILLAR, R. E.; COCHONNEAU, G.; VAUCHEL, P.; MOQUET, J.; BABY, P.; ESPINOZA, J. C.; LAVADO, W.; CARRANZA, J.; GUYOT, J. L. Sediment budget in the Ucayali River basin, an Andean tributary of the Amazon River. Sediment Dynamics from the Summit to the Sea. In: PROCEEDINGS OF A SYMPOSIUM HELD IN NEW ORLEANS, 2014, Louisiana, USA, Proceedings... Louisiana: IAHS Publ. 367, 2014.

SANTOS, A. L. M. R.; MARTINEZ, J. M.; FILIZOLA JUNIOR, N. P.; ARMIJOS, E.; ALVES, L. G. S. Purus River suspended sediment variability and contributions to the Amazon River from satellite data (2000-2015). Comptes Rendus Geoscience, v. 350, n. 1-2, p. 13-19, 2018. http://dx.doi.org/10.1016/j.crte.2017.05.004.

SARI, V.; CASTRO, N. M. R.; KOBIYAMA, M. Estimativa da concentração de sedimentos suspensos com sensores ópticos: revisão. RBRH: Revista Brasileira de Recursos Hídricos, v. 20, n. 4, p. 816-836, 2015. out./dez.

SHAHZAD, M. I.; MERAJ, M.; NAZEER, M.; ZIA, I.; INAM, A.; MEHMOOD, K.; ZAFAR, H. Empirical estimation of suspended solids concentration in the Indus Delta Region using Landsat-7 ETM+ imagery. Journal of Environmental Management, v. 209, p. 254-261, 2018. http://dx.doi.org/10.1016/j.jenvman.2017.12.070. PMid:29306142.

STERCKX, S.; KNAEPS, S.; KRATZER, S.; RUDDICK, K. SIMilarity Environment Correction (SIMEC) appliedto MERIS data over inland and coastal waters. Remote Sensing of Environment, v. 157, p. 96-110, 2015. http://dx.doi.org/10.1016/j.rse.2014.06.017.

TANRE, D.; HERMAN, M.; DESCHAMPS, P. Y. Influence of the back ground contribution upon space measurements of ground reflectance. Applied Optics, v. 20, n. 20, p. 3676-3684, 1981. http:// dx.doi.org/10.1364/AO.20.003676. PMid:20372238. 
THORNTON, K. W. Sedimentary process. In: THORNTON, K. W.; KIMMEL, B. L.; PAYNE, F. E. Reservoir limnology: ecological perspectives. New York: John Wiley e sons, Inc., 1990. 251 f.

TOU, J. T.; GONZALEZ, R. C. Pattern Recognition Principles. Massachusetts: Addison-Wesley Publishing Company, 1974.

TRIOS. RAMSES 40SXXX010. Spectral imaging radiometer to measure radiance or irradiance in UV, VIS and UV/VIS. Disponível em: http://www.trios.de/en/products/sensors/ramses.html Acesso em: 17 jan. 2017. 2010.

US Geological Suvey. Science for a Changing World. Department of the Interior. Product Guide: Provisional Landsat 8 Surface Reflectance Code (LARSC) Product. Version 3.4. Virgínia: US Geological Suvey, 2016.

VANHELLEMONT, Q.; RUDDICK, K. Turbid wakes associated with offshore wind turbines observed with Landsat 8. Remote Sensing of Environment, v. 145, p. 105-115, 2014. http://dx.doi. org/10.1016/j.rse.2014.01.009.

VERMOTE, E.; JUSTICE, C.; CLAVERIE, M.; FRANCH, B.; FRANCH, B. Preliminary analysis of the performance of the Landsat 8/OLI land surface reflectance product. Remote Sensing of Environment, v. 185, p. 46-56, 2016. http://dx.doi.org/10.1016/j. rse.2016.04.008.

VERMOTE, E., TANRÉ, D., DEUZÉ, J., HERMAN, M., MORCRET'TE, J., KOTCHENOVA, S. Second simulation of a satellite signal in the solar spectrum-vector (6SV). 6S User Guide Version 3. 2006. Disponível em: <http://6s.ltdri.org/pages/manual.html> Acesso em: 21 set. 2017.

VILLAR, R. E.; MARTINEZ, J. M.; ARMIJOS, E.; ESPINOZA, J. C.; FILIZOLA, N.; SANTOS, A.; WILLEMS, B.; FRAIZY, P.; SANTINI, W.; VAUCHEL, P. Spatio-temporal monitoring of suspended sediments in the Solimões River (2000-2014). Comptes
Rendus Geoscience, v. 350, n. 1-2, p. 4-12, 2018. http://dx.doi. org/10.1016/j.crte.2017.05.001.

VILLAR, R. E.; MARTINEZ, J. M.; TEXIER, M.; GUYOT, J. L.; FRAIZY, P.; MENESES, P. R.; OLIVEIRA, E. A study of sediment transport in the Madeira River, Brazil, using MODIS remote-sensing images. Journal of South American Earth Sciences, 2012. http://dx.doi.org/10.1016/j.jsames.2012.11.006.

YEPEZ, S.; LARAQUE, A.; MARTINEZ, J.-M.; DE SA, J.; CARRERA, J. M.; CASTELLANOS, B.; GALLAY, M.; LOPEZ, J. L. Retrieval of suspended sediment concentrations using Landsat- 8 OLI satellite images in the Orinoco River (Venezuela). Comptes Rendus Geoscience, v. 350, n. 1-2, p. 20-30, 2018. http://dx.doi. org/10.1016/j.crte.2017.08.004.

\section{Authors contributions}

Giancarlo Brugnara Chelotti: Author of the master's dissertation that resulted in this article. Participated in all stages: bibliographic review, collection, processing and analysis of the data and writing of the article.

Jean Michel Martinez: Supervisor of the master's dissertation that resulted in this article. Responsible for the guidance of the author and the applied methodology.

Henrique Llacer Roig: Co-supervisor of the master's dissertation that resulted in this article. Responsible for the guidance of the author and supply of equipment and laboratory for analysis and data processing.

Diogo Olivietti: PhD student of the same research line. Participated in the steps of data collection and processing, in addition to providing complementary data. 